\title{
HIMALAYAN GLACIATION AND ITS EFFECTS ON TERRESTRIAL AND FRESHWATER ANIMAL LIFE IN PENINSULAR INDIA
}

\author{
BY \\ SUNDER LAL HORA, D.Sc., F.R.S.E., F.Z.S., F.R.A.S.B., F.N.I. \\ Director, Zoological Survey of India, Indian Museum, Calcutta
}

\section{CONTENTS}

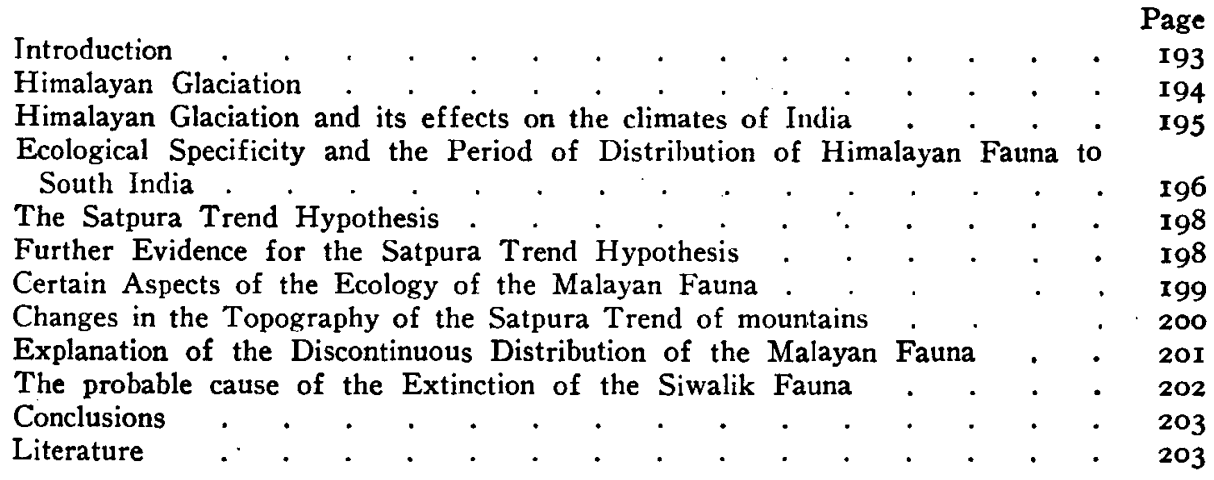

\section{INTRODUCTION}

One of the most remarkable features of the zoogeography of India is the occurrence of the so-called Malayan element in the freshwater and terrestrial fauna of the Indian Peninsula. This element is rich in species and genera of practically all groups of non-marine animals which are found in the hills of Peninsular India and Ceylon on the one hand and in the Eastern Himalayas, hills of Assam and Burma and Farther East on the other. The absence of this characteristic fauna from the rest of India and the present-day discontinuous distribution of a large assemblage of genera and species of Malayan affinities have attracted the attention of the naturalists for the last half a century or so.

Geologists have used these distributional anomolies as collateral evidence of a cold period having affected the whole of India and Ceylon in the late Tertiary or post-Tertiary times. In this connection, reference may be made from among others to Medlicott and Blanford (i879, pp. 1xx, 374, 375), Bijdragen tot de Dierkunde, Afl. 28. 
Oldham (1893, pp. I4, I5) and Wadia (1944, pp. 277, 278). Medlicott and BLANFORD in their introductory account of the Glacial Epoch (p. 1xx) stated:

... "Among the most potent disturbing causes that have affected the fauna of India in late geological times, the general refrigeration of the area in the glacial epoch has in all probability played a conspicuous part. The former extension of the Himalayan glaciers has been shewn to have been considerable; and the occurrence of Himalayan plants and animals on the higher ranges of Southern India may be due to the retreat of these species in the first place towards the equator, and subsequently, as the temperature increased, to the higher parts of the hills. As examples, the occurrence of a Himalayan rhododendron, of a wild goat allied to a Himalayan species, and of several Himalayan land shells on the Nilgiri and other Southerı Indian hills may be mentioned. ..... It is not impossible that the distinction between the Malabar and Malay faunas has been intensified by their separation, due to the climate of Northern India having been too cold for them in the glacial epoch."

In their treatment of the 'Fauna and Flora of the Indian Mountains' (p. 374), they recognised, however, that "Even on isolated peaks, such as Parasnath, 4,500 feet high, in Behar, and on Mount Abu in the Aravali (Aravelli) range, Rajputana, several Himalayan plants exist".

\section{HIMALAYAN GLACIATION}

Before considering the causes of the present-day distribution of the fauna and flora referred to above by MedlicotT and BLANFord, it is necessary to acquaint oneself with the effect of the Glacial Age on the climate of India. There is unmistakable evidence of the fact that, at the close of the Tertiary era and the commencement of the Quaternary, there was a great refrigeration of climate in Europe, North America and the northern world generally. The glacial conditions are stated to have prevailed so far south as $39^{\circ}$ latitude north. The countries which now experience a temperate climate, no doubt experienced the arctic cold of the polar regions during that period, but there seems no possibility of such condition having prevailed over the whole of India and Ceylon. For instance, there are no physical records of the Ice Age to the south of the Himalayas in the form of glaciated topography, moraine deposits or obstruction of drainage systems.

With regard to the Himalayas proper, the position is somewhat different. "On the Haramukh mountain in Kashmir a mass of moraine is described at an elevation of 5,500 feet. Grooved and polished rock-surfaces have been found at Pangi in the Upper Chenab Valley, and at numerous localities in the Sind and Lidar valleys, on cliff-faces at 7,500 feet level. In the Pir Panjal, above 6,500 feet, the mountains have a characteristic glaciated aspect, while the valleys are filled with moraines and fluvio-glacial drifts. On the southern slopes of the Dhauladhar range an old moraine (or what is believed to be such) is found at such an extraordinarily low altitude as 4,700 feet, while in some parts of Kangra, glaciers were at one time believed, though not on good evidence, to have descendeá below 3,000 feet level." (WADIA I944, p. 278). 
According to WADIA, "The ranges of the Middle Himalayas, which support no glaciers today, have, in some cases, their summits and upper slopes covered with moraines. The ice-transported blocks of the Potwar plains in Attock and Rawalpindi also furnish collaborative evidence to the same effect".

De Terra (see Waria, p. 280) found traces of four periods of ice advances and three periods of interglacial erosion in North-Western India. Terminal moraines of the first ice advance are at 5,500 feet, of the second in the Karewa beds, of the third at 6,500 feet and of the fourth at 8,000 to I0,000 feet.

- In the Eastern Himalayas, "Mr. W. T. Blandord had recorded the existence of moraines in Sikkim down 6,000 feet and that Major Godwin Austin has figured and described the beautiful examples of moraines, which he has discovered in the Naga Hills at an elevation of no more than 4,500 feet". (H. F. Blanford, 1877 , p. 4).

There is thus a concensus of opinion among Indian geologists, with whom I have had discussions on the glaciation in the Himalayas, that the glaciers in the Ice Age did descend to elevations of about 4,000 to 5,000 feet level but not very far below that zone.

\title{
HIMALAYAN GLACIATION AND ITS EFFECTS ON THE CLIMATES OF INDIA
}

An enquiry was made from the India Meteorological Department regarding the effect of change in the level of glaciers on the climate of India, and the following information was received:

\begin{abstract}
"Probably, glaciers do not directly affect the climatic conditions of the neighbouring areas to any considerable distance. But it does not follow therefrom that changes in the level of glaciers will not be associated with climatic changes. On the other hand it is quite likely that a change in the level of the glaciers may itself be a consequence of changes in climatic conditions and it would appear that information about the level of glaciers could be used to infer climatic change.

"It is very difficult to say with any confidence what the climate might have been under the conditions you specify. One can only try to make a plausible conjecture. At present Himalayan glaciers commence at about 12,000 feet. During the glacial period their level came down to 5,000 feet, i.e. by 7,000 feet. At an average lapse rate of $6^{\circ} \mathrm{C} / \mathrm{Km}$., this is equivalent to a decrease of $12^{\circ} \mathrm{C}$ or $21^{\circ} \mathrm{F}$ in the temperature over India during the glacial period compared to the present. The mean temperature in May, the hottest month, at Nagpur is now $97^{\circ} \mathrm{F}$. In the summer of the glacial period the temperature might have been about $76^{\circ} \mathrm{F}$ which is comparable with the present December temperature of $68^{\circ} \mathrm{F}$ at Nagpur. Thus the temperature conditions during the summers of the glacial periods would have resembled the present winter conditions."
\end{abstract}

A draft copy of the articles was sent to Lt. Col. R. B. S. Sewell, my late Chief and well-known Oceanographer, at Cambridge for comments and suggestions. He very kindly brought to my notice that

"In both oceans, Atlantic and Indian, there have been found a succession of cold phases alternating with warmer conditions. There can thus be little doubt that they were caused by the corresponding phases of the Glacial Epoch. 
"Phleger and Hamilton (I946) found three such phases in the North Atlantic and Stubbings (1939) got four in the Arabian Sea. These changes in the Foraminifera undoubtedly show that marine surface conditions were considerably cooler at intervals during the Glacial Epoch. Such changes have heen postulated to account for the changes that took place in the coral reefs of the tropics during this period, the temperature of the surface water becoming cooled to such an extent that coral growth was inhibited and the reefs were killed off and this indicates that the drop in temperature of the surface water was from $28^{\circ} \mathrm{C}$ down to $20^{\circ} \mathrm{C}$ and this must have had a profound effect on the climate of Peninsular India, with cool water masses on both sides."

The opinion of the India Meteorological Department was solicited on Col. SEWELL's observations and I was informed that "A decrease in the sea temperature from $28^{\circ} \mathrm{C}$ to $20^{\circ} \mathrm{C}$ is calculated to produce a $40 \%$ decrease in the moisture that can be picked up by air currents from the sea. Thus, even if the South-west Monsoon prevailed in the glacial period the associated rainfall would probably have been appreciably less than at present".

To summarise the above data, it may be stated that in the Malabar Zone of the peninsula, where the daily range of temperature is small throughout the year and the rainfall is almost entirely confined to the monsoon period, the effect of the Glacial Epoch was slight diminition of temperature and some decrease in rainfall, but both these conditions taken together would indicate that the relative high humidity, so characteristic of this area as well as of North-east India, was not affected in any way. As will be seen later, humidity is the chief controlling factor in the distribution of the so-called Malayan fauna.

\section{ECOLOGICAL SPECIFICITY AND THE PERIOD OF DISTRI- BUTION OF HIMALAYAN FAUNA TO SOUTH INDIA}

There are two very important observations which MedLicotT and BLANFORD have made with regard to the ecological factors governing the distribution of the Malayan fauna and flora and of their probable age in Southern India. With regand to ecology, they ovserved:

\footnotetext{
"The range in elevation of the temperate fauna and flora of the Oriental region in general appears to depend more on humidity than temperature, many of the forms, which, in the Indian hills, are peculiar to the higher ranges, being found represented by allied species at lower elevations in the damp Malay Peninsula and Archipelago, and some of the hill forms being even found in the damp forests of the Malabar coast."
}

The observations of MEDLICOTT and BLANFORD on the age of this fauna and flora and the possible ways of their dispersal are of still greater interest. They stated:

"That a great portion of the temperate fauna and flora of the Southern Indian hills has inhabited the country from a much more distant epoch than the glacial period may be considered as almost certain, there being so many peculiar forms. It is possible that the species common to Cey'on, the Nilgiris, and the Himalayas may have migrated at a time when the country was damper, without the temperature 
being lower, but it is difficult to understand how the plains of India can have enjoyed a damper climate without either depression, which would have caused a large portion of the country to be covered by sea, a diminished temperature which would check evaporation, or a change in the prevailing winds. The depression may have taken place, but the migration of animals and plants from the Himalayas to Ceylon would have been prevented, not aided, by the southern area being isolated by sea, so that it may be safely inferred that the period of migration and the period of depression were not contemporaneous. A change in the prevailing winds is improbable so long as the present distribution of land and water exists, and the only remaining theory to account for the existence of the same species of animals and plants on the Himalayas and the hills of Southern India is depression of temperature."

In the foot-note, the authors invited attention to the fact that this is a very interesting subject, which requires further enquiry, but one finds that their statements have been repeated verbatim by later geologists without giving much thought to this highly interesting subject. One possible objection to their theory of depression of temperature, MEDlicotT and Blanford themselves thought fit to answer. They stated in the foot-note on p. 375:

"It is true that many of the temperate damp-loving forms of the Nilgiris and Ceylon hills are forest forms, and it may be urged that they might have migrated when the plains of India were covered with forest. But, judging from what remains of the forest on the plains of the Carnatic, Deccan, Central Provinces, etc., the flora even when the whole was forest differed so widely from that of the hills, that it is improbable that any general diffusion of hill species could have taken place without a change of climate."

BlANFORD (I9OI, pp. 435, 436), in his memorable work on the distribution of vertebrate animals in India, Ceylon and Burma, opined that:

"Unless the temperature of India and Burma generally underwent a considerable diminution, it is not easy to understand how plants and animals of temperate Himalayan types succeeded in reaching the hills of Southern India and Ceylon, as well as those of Burma and the Malay Peninsula."

The above observations lead us to the following conclusions:

I. The Malayan fauna had already dispersed to the hills of Peninsular India before the commencement of the Glacial Epoch.

2. The dispersal of this fauna probably took place over a route covered with forests, thereby having a damper climate through an annual rainfall of over 75 inches distributed fairly uniformly throughout the year.

3. Throughout the Glacial Epoch, when there was some depression of temperature in the Peninsula and the monsoons were weaker, the same high relative humidity was maintained along the route by a reduction in evaporation as a result of diminished temperature.

4. The diminished temperature of the Peninsula as a result of the Glacial Epoch did not influence the distribution of the animals and plants, as relative high humidity still characterised their habitats.

It would thus seem probable that the only possibility worth investigation to explain this anomalous distribution is the likely continuity at some period of evergreen, moist, deciduous forests all over the earlier extensive range of the Malayan fauna and flora. 


\section{THE SATPURA TREND HYPOTHESIS}

In propounding their theory of considerable diminution in temperature in Peninsular India and Ceylon during the Ice Age, Medlicotr and Blanford failed to consider the 'possibility of the Satpura and Vindhya ranges of mountains being at one time much higher than what they are at the present day. In discussing the 'Distribution of Himalayan Fishes and its bearing on certain palaeogeographical problems', it was pointed out by the writer (I937, p. 255) that

\footnotetext{
"The new stocks of specialised hill-stream fishes from the east, not finding means to cross this barrier, were deflected towards south-west along the Satpura Trend which probably at that period stretched across India as a pronounced range from Gujrat to the Assam Himalayas. From Gujrat the hill-stream fauna migrated towards the South along the Western-Ghats and spread to the hills of the Peninsula in the extreme south."
}

With the conception of the Satpura Trend of Mountains as the main route of migration of Malayan fishes, intensive investigations were conducted to test this hypothesis and the results are summarised in the article entitled: 'On the Malayan affinities of the freshwater fish fauna of Peninsular India, and its bearing on the probable age of the Garo-Rajmahal Gap' (Hora, 1944). It has been inferred from these studies that the Vindhyas and the Satpuras were once much higher and were continuous with the Assam hills and that the Garo-Rajmahal Gap "is in all probability a very recent feature of the physiog. raphy of India". Since then much further evidence in support of this hypothesis has accumulated and it has been shown that the distribution of specialised hill-stream fishes could only be possible through the continuity of torrential streams at one time or another over the entire length of the SatpuraVindhya Trend of Mountains (HoRA, 1947). Diminution of temperature in the Peninsula could only. influence, if it did influence, the migration of terrestrial animals but could not make the fishes forsake the streams and to move towards the equator in the first instance and later to climb up the hills in search of cooler habitats. Unfortunately, MEDLICOTT and BLANFORD did not at all take the distribution of freshwater fishes into consideration, otherwise they would have been obliged to give up their theory of the diminution of temperature as a factor accounting for the distribution of the Himalayan fauna and flora to the hills of Touthern India.

\section{FURTHER EVIDENCE FOR THE SATPURA TREND HYPOTHESIS}

There is not only now unmistakeable evidence of the Satpura Trend as having served the route of migration of the torrential fishes, but I (I948) have recently found that the same holds true in the case of Chelonians. Mr. Salim Ali, the well-known Indian Ornithologist, in a series of personal letters has lent support to this hypothesis from the distribution of binds and 
his latest communication is worth quoting. He states in his letter, dated the 27th April 1948, as follows:

"You will be glad to hear that I have obtained some significant confirmatory evidence in the Surat Dangs of your Satpura theory. This evidence confirms that certain species confined to evergreen and moist deciduous forests in Travancore and in other parts of Western Ghats definitely extend north to the junction of the Satpuras with the Western Ghats. I had found these species there before, but was not sure of their status. I am here referring to those species of course that are also found in the Eastern Himalayas and Malaya."

More and more evidence from various groups of aquatic and terrestrial animals is now accumulating in favour of the Satpura Hypothesis, but it is true, as pointed out by MEDLicotT and BLANFord, that it is improbable that any general diffusion of hill species could have taken place without a change of climate in earlier times.

\section{CERTAIN ASPECTS OF THE ECOLOGY OF THE MALAYAN FAUNA}

The peculiar Himalayan fauna found in the hills of Southern India has the following abiotic characteristics in its environment:

In the case of aquatic animals, swift currents, characteristic of the Khasi Hills in the east and Malabar Hills in the west, are essential for their existence, as the structural modifications undergone by the majority of them fit them only to this type of habitat. In the case of terrestrial animals, dampness seems to be the most essential factor in their environment. For instance, the most characteristic feature. of climate of the Assam hills is dampness at all seasons in conjunction with the moderately high and comparatively equable temperature. The rainy seasons extend from April to November and generally there is copious rain, the higher elevat on getting over 100 inches of rain while the plains may get anything between 70 inches and 100 inches. The mean temperature in the flain is $95^{\circ} \mathrm{F}$ and it very rarely goes upto $100^{\circ} \mathrm{F}$. Mean annual humidity is $80 \%$.

To satisfy both the terrestrial and aquatic conditions for the migration of this fauna, it is necessary to contemplate that the Satpuras must once have had over one hundred inches of anual rainfall spread over a greater part of the year so that the ecological conditions for the fauna must have been analogous to those now prevailing in the hills of Assam or the hills of Southern India. Rainfall thus appears to be the most important factor in the ecology of the Malayan forms, as vegetation, temperature, humidity, etc.; are all dependent on rainfall. An enquiry was, therefore, made from the Director-General of Observatories in India as to the heights to which the Satpuras must be raised so as to produce a local precipitation of 150 to 200 inches of rainfall per annum. In his letter of the 24th April, 1948, Dr. S. K. BANERJI replied as follows: 


\begin{abstract}
"The satpura range will have to be raised to about 8,000 feet above sea level to have an annual rainfall of 200 " during the monsoon and to 6,000 feet above sea level for the rainfall to be $150^{\prime \prime}$. The same value will probably apply to the Vindhya range as well. It should however be understood that these computed values only indicate the order of magnitude of the maximum possible precipitation when the heights are increased.

"As far as the Western Ghats are concerned, the rainfull distribution is more in the central parts of the range and less along the northern extremeties and southern extremeties. At the upper and the lower ends of the Ghats, the monsoon tends to flow round, while at the Central part, it flows over. This accounts for the differences in the rainfall distribution. There are places in the Bombay section of the Western Ghats which get as much rain, if not more, than the Travancore section."
\end{abstract}

The Satpuras were undoubtedly once connected with the northern section of the Western Ghats, the southern section of which was at that time connected with the hills of Ceylon so there were no gaps at one time round which the monsoon could flow. So when the Vindhyas and the Satpuras were continuous with the Assam hills and the Himalayas, they were probably 5,000 to 6,000 feet high and were continuous in the west with the Aravalli hills to the north and the Western Ghats to the south. Such a topography could ensure continuity of evergreen and moist deciduous forests for the migration of terrestrial forms and torrential perennial streams for the migration of swift current animals from the Assam Himalayas to the hills of Ceylon. Evidence of evergreen and moist deciduous forests in the region of the Satpuras is afforded by the post-pliocene Narbada fauna. Here we have remains of Hippopotamus and Rhinoceros besides elephants, which indicate climatic conditions similar to those of the Assam hills of today.

\title{
CHANGES IN THE TOPOGRAPHY OF THE SATPURA TREND OF MOUNTAINS
}

With regand to the likely topographic changes in the northern part of the Peninsula, Dr. J. B. Auden of the Geological Survey of India, has very kindly directed my attention to Dr. Dunn's account of the post-Mesozoic movements in this region. DunN (1939, pp. I37-I42) has indicated that there was a rise of 2,500 feet in the Chota Nagpur plateau and that this rise may have been concomitant with the Himalayan movements. In a note to the writer, Dr. AUden has stated that the downwarp resulting from the Himalayan movements began in the orogenic furrow now occupied by the Siwaliks, and continued in the Lahore and North-Bihar alluvial basins. The Peninsula rose and the hinge zone between the Gangetic downwarp and the Chota Nagpur upwarp was somewhere in the latitude of the Rajmahal Hills.

With regard to the Satpuras, Dr. Auden has given me the following note:

"Crookshank (Mem. Geol. Surv. Ind., LXVI, p. 264, 1936) has shown the existence of post Deccan-Trap faulting along the northern edge of the Satpuras which indicated an uplift of the Satpura relative to the downfaulted Narbada zone. Not much is known about the northern edge of the Narbada Valley, but this may be downfaulted. De Terra considers that the visible deposits of the Narbada trough belong 
to the Acheulian or lower Paleolithic, and suggests that below these deposits probably come the equivalents of the Upper Siwaliks. Dr. Hora has suggested in conversation that the Narbada deposits may be regarded as equivalent to the Siwaliks, and formed in a trough below the Satpuras. This is very probably so, and the Satpuras are likely to have lost a considerable thickness of Upper Gondwanas and Deccan Traps from the Pachmari plateau in the process of filling up the trough to the north.

"What should probably be concluded from the little recorded evidence is that the zone in the northern Peninsula between Chota Nagpur, and the Vindya and Satpura ranges was periodically subjected to epeirogenic rise, sympathetically with the Himalayan movements, and may formerly have been at greater elevations than now, but that in more recent times denudation has removed a considerable thickness of rocks from these ranges. In the eastern part of the Vindhyan outcrop the Rewa and Bhauder series are absent, only the Semris and Kaimurs being present. In Hoshangabad and the Dhar forest the Rewa and Bhauder series are some 10,000 feet thick, but it is very probable that in their former extensions to the east they were considerably thinner. Nevertheless, a thickness of some 3,000-4,000 feet of upper Vindhyan may have been removed in the east. The present elevation of the topmost Kaimur rocks north of the Son Valley is about 2,000 feet, so that the original elevation, before the Rewa and Bhauder series were eroded, would have been perhaps 5,000 to 6,000 feet, provided there has been no change in crustal elevation during the period of erosion. In the central parts of the Vindhyan outcrop, where all four divisions of the Vindhyans are still preserved, it is difficult to know at what elevation the top of the sedimentary pile may formerly have existed. The present top is a plateau between 1,000 and 2,000 feet in elevation."

With regard to the changes in the extra-Peninsula, Wadia (1943, p. 4I) has pointed out that

\footnotetext{
"The period inmmediately succeeding the Tertiary was a period of intense orogenic activity in North-West India, it being the final phase of the uplift of the Himalayas, during which, to judge from various evidence observed in the Pir Panjal, the Kashmir Himalayas were lifted from 5,000 to 8,000 feet. The tilting and folding of the river and lake-formed Karewas with the fossil plants, fish, batrachians, elephas, rhinoceros, and a few human implements, and their extension to altitudes upto II,500 feet afford a rough estimate of the extent of the movements and of their time duration."
}

\section{EXPLANATION OF THE DISCONTINUOUS DISTRIBUTION OF THE MALAYAN FAUNA}

With the denudation and erosion of the Vindhya-Satpura Range, its height came down gradually and in consequence the climatic conditions began to change with the lowering of the rainfall. In the Chota Nagpur hills alone we find some remnants of the old fauna and flora, whereas in the drier parts of their earlier continuous range they have probably died out or are to be found in localised habitats with suitable environmental conditions. The Chota Nagpur plateau is the region of annual rainfall of 50 to 60 inches. The rainy season is confined to June to September with a few showers in May and October. The sea-level mean temperature is about $80^{\circ} \mathrm{F}$ with a mean annual humidity of $65 \%$. During the rainy season, this region has the same climate as Assam while in other seasons, with the exception of two winter month, it is definitely drier and hotter. The forms of the old fauna locked up in 
this region have developed racial characters as a result of habitudinal segregation from the parent stock over a long period.

It will thus be clear that the present-day anamolies in the distribution of Himalayan forms to the hills of South India can be explained on the basis of the Satpura Trend Hypothesis. Their present isolation on hills is due to the change in climatic conditions in the intervening reg.ons consequent on the fragmentation and lowering of the Satpuras Trend of mountains.

Dr. J. B. Auden of the Geological Survey of India, having read the manuscript of the article, has expressed the view that the main points raised in this article cannot be challenged and "that the Himalayan glaciation was not the controlling factor in the dispersal of the fauna and flora of southern India, and that the formerly more elevated Vindhyan-Satpura ranges may have played an essential role".

Mr. P. N. Mukherjee, Palaeontologist to the Geological Survey of India, has fully agreed with Dr. AUden that "the Himalayan glaciat:on was not the controlling factor in the dispersal of the fauna and flora of southern India and that the Vindhya-Satpura ranges must have played an important part".

Dr. K. JACOB, Palaeobotanist to the Geological Survey of India, observed that

"Dr. Hora's main conclusion that the Himalayan glaciation had nothing to do
with the present day distribution of fauna and flora cannot be refuted. It would
appear from a comparison of the recent flora with the first interglacial plants of
the Karewas, that even in a region such as Kashmir, the inter-play of monsoon
conditions and increased elevation of land (rather than glaciation), ultimately in-
fluenced the final balance of vegetation. Much less did the glaciation exert any
influence in the dispersal of Himalayan elements to the hills of southern India."

\section{THE PROBABLE CAUSE OF THE EXTINCTION OF THE} SIWALIK FAUNA

The extinction of the Siwalik mammals is generally adduced as an evidence of an Ice Age in the Pleistocene epoch in India. This view was first propounded by Wallace (1876, p. 150 ) and has been repeated in all books on Indian geology. It is true that "The great Carnivores, the varied races of elephants belonging to no less than twenty-five to thirty species, the Sivatherium and numerous other tribes of large and highly specialised Ungulates which found such suitable habitats in the Siwalik jungles of the Pliocene epoch, are to be seen no more in an immediately succeeding age". (WaDIA 1944, p. 279).

It must, however, be remembered that along with the extinction of the Siwalik fauna, the post-Pliocene Narbada fauna comprising elephants, Hippopotamus and Rhinoceros also became extinct and from what we have stated above, glaciation in the Himalayas cannot account for the extinction of the Narbada fauna. The Siwalik and the Narbada faunas were probably contemporaneous and their extinction was also probably due to the same cause. 
We have seen above that the Alpine-Hamalayan movements gave a last heave at the beginning of the Upper Pleistocene and that the Kashmir Himalayas were lifted from 5,000 to 8,000 feet during this period of intense orogenic activity. We have also seen that the movements in the northern part of the Peninsula were concomitant with those of the Himalayas. Is it not possible, therefore, that the Siwalik and the Narbada faunas died out about the same time as a result of these orogenic movements? The geological history of these movements given above is highly suggestive of this probability.

\section{CONCLUSIONS}

The theory of the Glacial Age having affected the distribution of the terrestrial and freshwater faunas and floras of India as far south as Ceylon has been found to be untenable. The extension of distribution of Himalayan plants and animal on the hills of Southern India has been explained on the basis of the Satpura Trend Hypothesis advanced by the writer in 1937 to account for the discontinuous distribution of torrential fishes in India. The most potent disturbing cause that affected the fauna of India in the late geological times appears to be the post-Pliocene Alpine-Himalayan orogenic movements. These movements appear to have been responsible for the rise of the Satpura-Vindhya Range concomitant with the rise of the Himalayas and for the extinction of the large mammals of the Siwalik and the Narbada series.

In contributing this article for the Commemoration Volume, I wish to pay my humble tribute to the very valuable work done by Prof. L. F. DE BEAUFORT on the zoogeography of land and freshwater animals of the Oriental Region. It is hoped that the above discuss:on of the probable role of Glacial Epoch in the distribution of Indian animals will now afford new avenues of thought to the geographers and geologists interested in the evolution of the present-day geography of India. From the literature, it appears that undue importance had been attached to the influence of the Ice Age to the detriment of a proper understanding of the palaeogeography of India.

\section{LITERATURE}

Blanford, H. F., 1877. On Himalayan Glaciation. Discussion. Proc. As. Soc. Bengal, 4. Blanford, W. T. Igor. The Distribution of Vertebrate Animals in India, Ceylon and Burma. Trans, Roy. Soc. London (B), 194, 335-436.

DunN, J. A., I939. Post Mesozoic movements in the northern part of the Peninsula. Mem. Geol. Surv. India, 73, 137-142.

Hora, S. L., 1937. Distribution of Himalayan Fishes and its bearing on certain Palaeogeographical problems. Rec. Ind. Mus., 39, 251-259.

- 1944 . On the Malayan Affinities of the Freshwater Fish Fauna of Peninsular India, and its bearing on the probable age of the Garo-Rajmahal Gap. Proc. Nat. Inst. Sci. India, 10, 423-439.

- 1947. Torrential Fishes and the Significance of their Distribution in Zoo-geographical Studies. Bull. Nat. Geog. Soc. India, 7, 1-10. 
HoRA, S. L., 1948. The Distribution of Crocodiles and Chelonians in Ceylon. India, Burna and Farther East. Proc. Nat. In t. Sc. India, 14. 285-310.

Medilcott, H. B. and Blanford, W. T., I879. A Manual of the Geology of India, 2 parts (Calcutta).

Oldham, R. D., 1893. A Manual of the Geology of India (Calcutta).

Phleger, F. B. Jn. and Hamilton, W. A., 1946. Foraminifera of two Submarine Cores from the North Atlantic Basin. Bull. Geol. Soc. America, 57.

Stubbings, H. G., 1939. Stratification of Biological Remains in Marine Deposits. Sci. Rep. John Murray Exped,, 3, 159-192.

Wadia, D. N., 1943. The Pliocene-Pleistocene Boundary in North-Western India. Proc. Nat. Inst. Sci. India, 9, 37-42.

-, 1944. Geology of India, 2nd Edition (London):

Wallace, A. R., 1876. The Geographical Distribution of Animals I, 150-15I (London). 